Jurnal Media Pertanian Vol. 1 No. 2 Tahun 2016 Hal. 85 - 90

Media Komunikasi Hasil Penelitian dan Review Literatur Bidang Ilmu Agronomi

ISSN $2503-1279$

\title{
HUBUNGAN PERSENTASE SERANGAN HAMA \\ PENGGEREK BUAH KOPI (Hypothenemus hampei Ferr.(Coleoptera: Scolytidae)) dengan DUGAAN KEHILANGAN HASIL di KECAMATAN BETARA TANJUNG JABUNG BARAT
}

\author{
Hayata \\ Program studi Agroteknologi, Fakultas Pertanian Universitas Batanghari \\ Jl. Slamet Riyadi-Broni, Jambi 36122 Telp. +62074160103 \\ email : atahayata@yahoo.com
}

\begin{abstract}
Hypothenemus hampei is one of the main causes of the decrease in production and quality of coffee. The fenomena of this damage can be indicted by dwarfing fruit color changing to a reddish yellow, and finally the fall resulted in a decrease in the quantity and quality of production. This production loss was affected by the attack level of coffe pest. Symptoms of coffe pest attack (PBKo) can be identicated by its attacting form where PBKo can destroy both the unripe and ripe coffe. This research aims to know the relationship attacks Percentage the production loss due to the pest attack. Hypothenemus hampei Ferr. (Coleoptera: Scolytidae) in Betara subdistrict of Tanjung Jabung Barat regency. This research has been conducted in JulyAugust 2016. This research using survey method with linear regression analysis i.e. regression between the percentage of attacks and the percentage of production loss. The attack percentage of PBKo pests in the Parit Panglong Betara village range between $8.20-17.76 \%$. The percentage highest production loss results on red skin color coffee $7.11 \%$ and low on coffee colored skin green beans 3.95\%. The percentage of PBKo pest attack had not showed a very strong relationship with the level of production loss.
\end{abstract}

Keywords: Hypothenemus hampei, coffee

\begin{abstract}
Abstrak
Hypothenemus hampei merupakan salah satu penyebab utama penurunan produksi dan mutu kopi. Kerusakan yang ditimbulkannya berupa buah menjadi tidak berkembang, berubah warna menjadi kuning kemerahan dan akhirnya gugur mengakibatkan penurunan jumlah dan mutu hasil. Kehilangan hasil dipengaruhi oleh tingkat serangan hama penggerek buah kopi. Gejala serangan hama penggerek buah kopi (PBKo) dapat diketahui dari bentuk serangan dimana PBKo dapat menggerek buah kopi yang masih muda sampai dengan yang masak. Penelitian ini bertujuan untuk mengetahui hubungan Persentase serangan dengan dugaan kehilangan hasil akibat serangan hama penggerek buah kopi Hypothenemus hampei Ferr.(Coleoptera:Scolytidae) di Kecamatan Betara Kabupaten Tanjung Jabung Barat. Penelitian dilaksanakan pada bulan Juli-Agustus 2016. Penelitian ini menggunakan metode survei dengan analisis regresi linier yaitu regresi antara persentase serangan dengan persentase kehilangan hasil. Persentase serangan hama PBKo di Desa Parit Panglong Betara berkisar antara 8,20 - 17,76 \%. Persentase kehilangan hasil yang tertinggi didapatkan pada kopi yang warna kulit merah $7,11 \%$ dan terendah pada kopi yang berwarna kulit biji hijau 3,95\%. Persentase serangan hama PBKo tidak memperlihatkan hubungan yang kuat dengan tingkat kehilangan hasil
\end{abstract}

Kata kunci : Hypothenemus hampei, kopi 
Jurnal Media Pertanian Vol. 1 No. 2 Tahun 2016 Hal. 85 - 90

Media Komunikasi Hasil Penelitian dan Review Literatur Bidang Ilmu Agronomi

ISSN $2503-1279$

\section{PENDAHULUAN}

Kopi merupakan salah satu komoditas perkebunan yang peranannya cukup penting bagi perekonomian nasional, khususnya sebagai penyedia lapangan kerja, sumber pendapatan dan devisa negara. Perkebunan kopi mampu menyediakan lapangan kerja dan pendapatan kepada lebih dari 2 juta kepala keluarga petani dan menghasilkan devisa lebih dari US\$ 500 juta per tahun pada periode 1994-1998 (Herman, 2003).

Tanaman kopi (Coffea spp.) sebagian besar merupakan perkebunan rakyat dengan penerapan teknologi budidaya yang masih terbatas. Bila penerapan teknologi budidaya di perkebunan kopi rakyat tersebut diperbaiki, produksinya bisa ditingkatkan. Teknologi yang dianjurkan untuk diterapkan adalah teknologi budidaya kopi poliklonal (Ernawati, Ratna dan Slameto, 2008).

Sampai saat ini kopi masih menjadi salah satu komoditas ekspor penting pada sub sektor perkebunan. Serangga hama penggerek buah kopi (PBKo) Hypothenemus hampei Ferr. (Coleoptera: Scolytidae) merupakan hama yang sudah tidak asing lagi dan banyak ditemukan menyerang buah kopi di beberapa wilayah di Indonesia. Keberadaan hama ini dapat menurunkan produksi dan kualitas hasil secara nyata karena menyebabkan banyak biji kopi berlubang. Kehilangan hasil oleh hama PBKo dapat mencapai lebih dari 50\% (Zahro'in dan Yudi, 2013). Hypothenemus hampei merupakan salah satu penyebab utama penurunan produksi dan mutu kopi di Indonesa, bahkan di seluruh negara penghasil kopi. Kerusakan yang ditimbulkannya berupa buah menjadi tidak berkembang, berubah warna menjadi kuning kemerahan dan akhirnya gugur mengakibatkan penurunan jumlah dan mutu hasil..

Sistem pertanian monokultur menjadi faktor utama penyebab tingginya intensitas serangan $H$. hampei. Pertanaman kopi yang tidak memiliki naungan atau penggunaan tanaman lain sebagai pohon pelindung juga merupakan salah satu faktor yang paling mendukung (Kusureng dan Rismayani, 2010), sedangkan Syahnen, Yenni dan Ida, (2010) menyebutkan bahwa tanaman kopi yang rimbun dengan pemangkasan yang tidak sempurna serta banyaknya gulma semakin mendukung keberlangsungan hidup dan peningakatan populasi hama PBKo di lapangan karena sesuai dengan kebutuhan hidup PBKo.

Sebuah usaha pengelolaan hama terpadu telah digunakan terhadap penggerek buah kopi. Usaha utama adalah budidaya yang baik, pengendalian hayati, penggunaan perangkap berupa atraktan dan pengendalian secara kimia dengan menggunakan insektisida sintetis (Barera, 2008).

Di lapangan, ketika serangga mulai menggerek buah kopi berwarna hijau merupakan satu faktor yang menentukan tingkat keberhasilan hama dalam menggerek namun kandungan bahan kering harus lebih dari 20\%. Dari hasil di laboratorium menunjukkan bahwa preferensi sangat tinggi untuk kopi yang berwarna merah atau hitam, sehingga tidak mungkin memiliki produksi yang signifikan di lapangan, karena pada saat kopi mencapai warna tersebut, kopi telah diserang oleh serangga (Vega, Infante, Castillo dan Jaramillo,2009).

Gejala serangan hama penggerek buah kopi (PBKo) dapat diketahui dari bentuk serangan dimana PBKo dapat menggerek buah kopi yang masih muda sampai dengan yang masak. Serangan PBKo ini pada umumnya hanya dilakukan oleh kumbang dewasa yaitu kumbang betina yang sudah kawin yang akan mengerek buah kopi. Hama ini masuk ke dalam buah dengan cara membuat lubang pada ujung buah. Kumbang betina menyerang buah kopi yang sedang terbentuk (endosperm masih lunak). 
Jurnal Media Pertanian Vol. 1 No. 2 Tahun 2016 Hal. 85 - 90

Media Komunikasi Hasil Penelitian dan Review Literatur Bidang Ilmu Agronomi ISSN $2503-1279$

Buah Kopi yang terserang PBKo, pada buah muda yang masih memiliki endosperm lunak, buah muda tersebut tidak dapat berkembang lebih lanjut, bahkan busuk dan gugur. Pengguguran buah kopi muda dapat mencapai $7-14 \%$ dari produksi (Anonim, 1995). Kerusakan berat dapat terjadi pada saat buah kopi mengeras, karena selain menggerek dan memakan biji kopi, kumbang ini juga berkembang biak di dalam biji sehingga biji kopi menjadi cacat dan berlubang-lubang sehingga kopi yang dihasilkan adalah kopi pasar yang berkualitas rendah dengan kerusakan yang ditimbulkan dapat mencapai 30-80\% dari produksi (Junianto, 2000).

Penelitian ini bertujuan untuk mengetahui hubungan persentase serangan dengan dugaan kehilangan hasil akibat serangan hama penggerek buah kopi Hypothenemus hampei Ferr.(Coleoptera : Scolytidae) di kecamatan Betara kabupaten Tanjung Jabung Barat

\section{METODE PENELITIAN}

Penelitian dilakukan mulai bulan Juni sampai Agustus 2016. Penelitian ini dilaksanakan di desa Parit Panglong kecamatan Betara kabupaten Tanjung Jabung Barat propinsi Jambi. Pengamatan dilakukan di Laboratorium Dasar Fakultas Pertanian Universitas Batanghari Jambi. Bahan yang digunakan adalah tanaman kopi Liberika (Coffea liberica), hama PBKo H. hampei, label, karet dan kantong plastik. Alat yang digunakan adalah ember, timbangan analitik, pisau scalpel, cawan, loup, mikroskop, kalkulator dan kamera.

Penelitian ini menggunakan metode purposive sampling di desa pada kecamatan Betara kabupaten Tanjung Jabung Barat. Untuk lokasi pengamatan dengan masingmasing sebanyak empat titik pengambilan sampel. Populasi dari penelitian ini adalah kebun kopi yang dibagi dalam 4 daerah dalam satu desa dan sampel penelitian ini adalah $10 \%$ dari keseluruhan populasi tanaman kopi.

Setiap pohon sampel terdiri dari 4 ranting pengamatan. Pemberian label dilakukan pada setiap ranting yang menjadi bagian sampel pengamatan. Pengambilan data dilakukan dengan menghitung buah kopi pada ranting yang menjadi sampel kemudian menentukan nilai persentase serangan. Hama diidentifikasi dengan cara mengamati buah kopi yang terserang dengan menggunakan alat bantu loupe dan mikroskop.

Peubah yang diamati meliputi persentase serangan $H$. hampei menggunakan rumus $\mathrm{P}=\frac{A}{B} \times 100 \%$, persentase kehilangan hasil dengan rumus $\mathrm{P}=\frac{B}{A} \times 100 \%$

Analisis data menggunakan regresi linier $\mathrm{Y}=\mathrm{a}+\mathrm{bX}$ antara persentase serangan dengan persentase kehilangan hasil., untuk menguji apakah korelasi tersebut signifikan atau tidak, maka dilakukan uji signifikan $\alpha=0,05$ 
Jurnal Media Pertanian Vol. 1 No. 2 Tahun 2016 Hal. 85 - 90

Media Komunikasi Hasil Penelitian dan Review Literatur Bidang Ilmu Agronomi ISSN $2503-1279$

\section{HASIL dan PEMBAHASAN}

Hasil pengamatan terhadap persentase serangan hama PBKo di kebun kopi rakyat desa Parit Panglong Betara, disajikan pada Tabel 1

Tabel 1. Rerata persentase serangan hama PBKo pada perkebunan Kopi rakyat di desa Parit Panglong Betara

\begin{tabular}{cc}
\hline Kebun & Persentase Serangan $(\%)$ \\
\hline Kebun 1 & 17.76 \\
Kebun 2 & 13.48 \\
Kebun 3 & 8.12 \\
Kebun 4 & 8.20 \\
Rerata & 11.89 \\
\hline
\end{tabular}

Dari Tabel 1 dapat dilihat bahwa pesentase serangan hama PBKo di desa Parit Panglong pada empat tempat pengamatan cukup bervariasi rata-rata mencapai $11,89 \%$. Pesentase serangan yang tertinggi di dapat pada kebun 1 yaitu mencapai $17,76 \%$, sedangkan yang terendah di dapat pada kebun 3 yaitu sebesar $8,12 \%$. Tingginya persentase serangan pada kebun 1 secara umum terlihat karena kebun kopi kurang dipelihara petani, sehingga hama PBKo berkembang sedemikian rupa. Sedangan pada kebun 3 berkurangnya persentase serangan disebabkan oleh adanya upaya petani melakukan pengendalian hama PBKo dengan cara menggunakan alat perangkap hama, namun alat yang digunakan masih sedikit, sehingga masih ada hama PBKo yang menyerang buah kopi.

Pada kebun 1 dan 2 pengendalian sudah dapat dilakukan karena sudah merugikan petani. Prastowo et.al (2010) menyebutkan bahwa serangga hama PBKo masuk dari ujung buah baik biji yang masih berada pada pohon maupun pada buah yang telah jatuh ke tanah. Pengendalian harus dilakukan bila persentase serangan diatas $10 \%$. Tingkat serangan sebesar $20 \%$ dapat mengakibatkan penurunan produksi sekitar 10\% (Zahro'in dan Yudi, 2013).

Dari pengamatan yang telah dilakukan terhadap persentase kehilangan hasil akibat serangan hama PBKo pada perkebunan kopi rakyat di desa Parit Panglong Betara didapatkan hasilnya yang dirangkum pada Tabel 2.

Tabel 2. Rerata persentase kehilangan hasil akibat serangan hama PBKo pada perkebunan Kopi rakyat di Desa Parit Panglong Betara

\begin{tabular}{ccccc}
\hline & \multicolumn{3}{c}{ Persentase Kehilangan(\%) } & \\
Kebun & Merah & Kuning & Hijau & Total \\
\hline Kebun 1 & 8.45 & 6.25 & 5.25 & 19.95 \\
Kebun 2 & 7.25 & 5.10 & 4.10 & 16.45 \\
Kebun 3 & 6.35 & 4.20 & 3.15 & 13.70 \\
Kebun 4 & 6.40 & 4.15 & 3.30 & 13.85 \\
Total & 28.45 & 19.70 & 15.80 & 63.95 \\
Rerata & 7.11 & 4.93 & 3.95 & 15.99 \\
\hline
\end{tabular}

Dari Tabel 2 di atas dapat dilihat bahwa berdasarkan tingkat kematangan buah kehilangan hasil tertinggi didapatkan pada buah yang berwarna merah $7,11 \%$ dan 
Jurnal Media Pertanian Vol. 1 No. 2 Tahun 2016 Hal. 85 - 90

Media Komunikasi Hasil Penelitian dan Review Literatur Bidang Ilmu Agronomi

ISSN $2503-1279$

terendah didapatkan pada buah yang berwarna hijau (buah yang masih muda) sebesar $3,95 \%$. Hal ini menunjukkan bahwa sebagian besar serangga hama PBKo menyerang buah dengan cara menggerek yang masih muda dan meletakkan telurnya sejak buah masih berwarna hijau (muda) bersamaan dengan perkembangannya hingga buah kopi berwarna merah. Namun ada juga serangga menggerek buah kopi berwarna kuning dan merah. Vega, et.al. (2009) menyatakan bahwa mengenai preferensi hama PBKo lebih tingi pada buah kopi berwarna merah dan hitam. Secara keseluruhan kehilangan hasil pada kebun 1 bisa mencapai 19,95\% dan terendah pada kebun 3 mencapai 13,70\%.

Berdasarkan Tabel 2, dapat dilihat bahwa persentase kehilangan hasil buah kopi di desa Parit Panglong Betara sudah termasuk dalam kategori serangan cukup berat, secara rata-rata kehilangan hasil yang didapat akibat serangan PBKo adalah sebesar 15,99\%. Arief, Mesin, Saragih dan Rahmadani (2011) menyatakan bahwa, serangan PBKo dapat menurunkan produksi hingga 20-30\% bahkan tidak jarang petani yang gagal panen.

Hubungan persentase serangan dengan persentase kehilangan hasil perhitungan yang dibuat berdasar analisis regresi ditampilkan pada Tabel 3.

Tabel 3. Hasil analisis regresi antara persentase serangan hama PBKo dengan kehilangan hasil buah kopi

\begin{tabular}{clll}
\hline No & Warna buah & Persamaan regresi & $\mathrm{R}$ \\
\hline 1 & Merah & $\mathrm{Y}=10174.42-855.114 \mathrm{X}$ & 0.001 \\
2 & Kuning & $\mathrm{Y}=15114.70-1270.8 \mathrm{X}$ & 0.291 \\
3 & Hijau & $\mathrm{Y}=17335.62-14157.67 \mathrm{X}$ & 0.297 \\
\hline
\end{tabular}

Hasil pendugaan model regresi linear didapatkan bahwa $\mathrm{R}^{2}$ pada masing-masing warna buah yaitu merah $0,1 \%$, kuning $29,1 \%$, dan hijau 29,7\%. Hal ini menunjukkan bahwa nilai hubungan regresi antara persentase serangan dengan persentase kehilangan hasil sangat rendah. Persentase serangan tidak memiliki hubungan yang sangat kuat terhadap persentase kehilangan hasil baik pada kopi berwarna merah, kuning, atau pun hijau. Semakin tinggi ataupun semakin rendah nilai intensitas serangan tidak berpengaruh nyata dengan persentase kehilangan hasil.

\section{KESIMPULAN}

Dari hasil pengamatan dan pembahasan dapat disimpulkan persentase serangan hama PBKo di desa Parit Panglong Betara berkisar antara 8,20-17,76\%. Berdasarkan warna kulit buah kopi, persentase kehilangan hasil yang tertinggi didapatkan pada kopi yang warna kulit merah $7,11 \%$ dan terendah pada kopi yang berwarna kulit biji hijau $3,95 \%$. Persentase serangan hama PBKo tidak memperlihatkan hubungan yang sangat kuat dengan tingkat kehilangan hasil.

\section{DAFTAR PUSTAKA}

Arief MCW, T Mesin, R Saragih dan Rahmadani. 2011. Panduan Sekolah lapang Budidaya Kopi konservasi, Berbagi Pengalaman dari Propinsi Sumatera Utara. Conservation International Indonesia. Jakarta.

Barrera JF.2008. Coffee Pests and Their Management. in: Capinera J L, editor. Encyclopedia of Entomology. 2nd ed. Springer. pp. 961-998.

Ernawati Rr, WA Ratna dan Slameto. 2008. Teknologi Budidaya Kopi Poliklonal. 
Jurnal Media Pertanian Vol. 1 No. 2 Tahun 2016 Hal. 85 - 90

Media Komunikasi Hasil Penelitian dan Review Literatur Bidang Ilmu Agronomi ISSN $2503-1279$

Balai Besar Pengkajian dan Pengembangan Teknologi Pertanian.Badan Penelitian dan Pengembangan Pertanian. Lampung.

Hindayana D, J Dewi, P Djoko, Gregory, NRP Gusti, M James, U Kasumbogo, S Maruddin, M Paul dan Ryatno. 2002. Musuh Alami, Hama dan Penyakit Tanaman Kopi. Proyek Pengendalian Hama Terpadu Perkebunan Rakyat, Direktorat Perlindungan Perkebunan, Direktorat Jendral Bina Produksi Perkebunan, Departemen Pertanian. Jakarta.

Kusureng MA dan Rismayani. 2010. Intensitas Serangan Kumbang Bubuk Buah (Stephanoderes Hampei) Pada Pertanaman Kopi di Desa Bulukmase, Kecamatan Sinjai Selatan, Kabupaten Sinjai, Sulawesi Selatan.

Prastowo BE, Karmawati, Rubijo, Siswanto, I Chandra dan SJ Munarso. 2010. Budidaya dan Pasca Panen kopi.Pusat Penelitian dan Pengembangan Perkebunan. Bogor.

Syahnen A, Yenni dan R T U S Ida. 2010. Rintisan Metode Pengamatan Hama Penggerek Buah Kopi (Hypothenemus hampei Ferr.) di Kabupaten Dairi Propinsi Sumatera Utara. Laboratorium Lapangan Balai Perbenihan dan Proteksi Tanaman Perkebunan (BBPPTP). Medan.

Vega FE, F Infante, A Castillo and J Jaramillo. 2009. The Coffee Berry Borer, Hypothenemus hampei(Ferrari) (Coleoptera:Curculionidae): A Short Review, with Recent Findings and Future Research Directions.Terrestrial Arthropod Reviews 2: 129-147.

Zahro'in E dan Y Yudi. 2013. Tingkat Serangan Penggerek Buah Kopi (PBKo) Hypothenemus hampei Ferr. di Propinsi Jawa Timur pada September 2013. Jawa Timur 